NBER WORKING PAPER SERIES

\title{
ADEQUACY OF INTERNATIONAL TRANSACTIONS AND POSITION DATA FOR POLICY COORDINATION
}

Lois Stekler

Working Paper No. 2844

NATIONAL BUREAU OF ECONOMIC RESEARCH

1050 Massachusetts Avenue

Cambridge, MA 02138

February 1989

Lois Stekler is an Economist at the Board of Governors of the Federal Reserve System. This paper is part of NBER's research program in International Studies. Any opinions expressed are those of the author not those of the National Bureau of Economic Research. 
NBER Working Paper \#2844

February 1989

\title{
ADEQUACY OF INTERNATIONAL TRANSACTIONS AND POSITION DATA \\ FOR POLICY COORDINATION
}

\section{ABSTRACT}

This paper examines the adequacy of data on current accounts and international indebtedness as measures of the need for policy adjustments and coordination. Doubts about the adequacy of these data have been raised by the growth of the global current account discrepancy and the statistical discrepancy in the U.S. International transactions accounts. The paper includes a brief review of the conclusions of the IMF working party on the world current account discrepancy and a detailed examination of the data on U.S. international transactions and net investment position. Both investigations support the conclusion that large shifts in reported data on current accounts and investment positions are likely to reflect real changes.

However, even if data were completely accurate, a given current account or investment position may not clearly indicate the magnitude of necessary policy changes because of lags in the adjustment process or underlying trends. This point is illustrated by the tendency of U.S. net investment income to grow as a result of the continued expansion of both claims and liabilities combined with a higher average rate of return on claims. This underlying tendency is likely to counteract, in part, the negative impact on future net investment income of growing U.S. net indebtedness to foreigners.

\author{
Lois Stekler \\ Board of Governors of \\ The Federal Reserve System \\ 20 th \& C Streets, Northwest \\ Stop 42 \\ Washington, DC 20551
}


Lois Stekler

\section{ADEOOACY OF INTERHATIOHAL TRANSACTIONS AND POSITION DATA FOR POLICY COORDIRATION \\ by Lois Stekler}

\section{A. INTRODUCTION}

The use of international policy coordination to limit exchange rate fluctuations assumes that there are generally agreed upon measures of disequilibrium. Frequently mentioned in this context are current accounts and international indebtedness. The focus of this paper is on the adequacy of data on current accounts and international investment positions as measures of the need for policy adjustments and coordination. Since I am most familiar with U.S. data, much of the discussion will focus on the U.S. current account and position.

There are several reasons for questioning the adequacy of current account and position data for use as measures of disequilibrium requiring international policy adjustments and coordination. High on this list has been the growth during the past decade in two discrepancies: the global current account discrepancy and the statistical discrepancy in the U.S. international transactions accounts.

\section{B. GLOBAL CURRENT ACCOUNT DISCREPANCY}

If data collection were completely accurate, each export recorded by one country would be matched by an equal import recorded by another country; the sum of all trade and services transactions for the whole world would equal zero. In practice, they do not sum to zero; reported imports of goods and services exceed reported exports. Moreover, as shown on table 1, this discrepancy has been very large in the 1980s and, although down substantially from the peak of $\$ 106$ bilion 
reached in 1982, it shows little sign of disappearing. The largest problems appear to be in the services accounts. When account is taken of the fact that shipping goods takes time and that exports at the end of one year may be recorded as imports in the next year, the residual asymmetry in the trade balance is positive and relatively small. The large negative discrepancy appears to be mainly the result of services transactions.

In response to the growing global discrepancy, the IMF set up a working party to investigate the reasons for its growth and to assess its implications for the usefulness of countries' current account positions as indicators of the need for policy adjustments. The working party concentrated on five areas: direct investment income, portfolio investment income, offshore financial centers and financial innovations, shipping and transportation, and unrequited transfer.

The working party concluded that the most important source of the global discrepancy was portfolio investment income and that the overriding factor was the emergence of a large body of cross-border assets recognized by the debtor countries but not by the creditors, coupled with a higher level of interest rates after 1979 (IMF 1987, 12). They reached this conclusion by comparing reported credits and debits with estimates based upon independent information on outstanding stocks of cross-border assets and liabilities and estimates of appropriate yields. In particular, heavy reliance was place on the banking data reported to the Bank for International Settlements (BIS).

The resulting adjustments to portfolio investment income were widespread; the working party added net credits to the current accounts of most world areas. Table 2 reproduces the working party's allocation 
of the services and transfer discrepancy, by country groups, for 1983 . For more detailed analysis, the interested reader is referred to the report of the working party (IMF 1987). In conclusion, they judged that the additions to countries' net current account receipts were not so concentrated in any single country or group of countries as to invalidate the basic thrust of analyses drawn from the uncorrected figures.

\section{U.S. STATISTICAL DISCREPANCY}

In contrast to the global discrepancy investigated by the IMF, the U.S. statistical discrepancy need not reflect errors and omissions in the reporting of current account transactions. In principle, the sum of all transactions in the U.S. balance of payments accounts, a double-entry bookkeeping system, should equal zero; for each transaction there should be two equal entries of opposite sign. In practice, the recorded accounts never sum exactly to zero because the data that would reflect the debit and credit counterparts of each single transaction generally are obtained from different sources. A positive statistical discrepancy represents some combination of net unrecorded exports of goods and services to foreigners and net unreported capital inflows from abroad. The growth of the statistical discrepancy in the U.S. international transactions accounts is a relatively recent development. In both the 1950 's and the $1960^{\prime} \mathrm{s}$ the statistical discrepancy was close to zero. (See chart 1.) In contrast, during the early 1970's there were substantial net unrecorded outflows or payments. Since 1974 a positive statistical discrepancy indicating net unrecorded receipts or inflows has developed. This increase in magnitude is not just the result of the inflation of nominal values. Consider, for example, the ratio of the 
statistical discrepancy to the value of trade (the average of recorded exports and imports of goods and services). The mean absolute value of this ration was .02 in the $1950^{\prime} \mathrm{s}$ and the $1960^{\prime} \mathrm{s}$, but .05 in the $1970^{\prime} \mathrm{s}$ and .06 in the $1980^{\prime} \mathrm{s}$. The peak values for this ratio in the postwar period were. 14 in 1971 and . 10 in 1982.

\section{Possible Explanations}

\section{a. Early focus on capital flows}

In the early $1980^{\prime} \mathrm{s}$, it was assumed that the sudden increase in the positive discrepancy was largely accounted for by unrecorded capital flows. The wide quarterly swings in the size of the statistical discrepancy also supported that conclusion. It was recognized that errors and omissions occurred in the reporting of trade transactions, but there seemed little reason to assume that these errors would suddenly increase or that they would vary widely from quarter to quarter.

Previous periods of relatively large positive statistical discrepancies had coincided with unsettled political and economic conditions abroad. The ratio of the value of the statistical discrepancy to trade was about as high as or higher than the 1979-1980 levels (.08) in certain Depression years (1934, 1935, and 1937), the early years of World War II (1939-41), and 1948. It seemed reasonable to assume that these earlier episodes were associated with the flight of capital to a safe haven in the United States in forms that were not fully reported, either because these investors wanted to remain anonymous or because the reporting system failed to catch many small investors. The only other year since World War II when the statistical discrepancy was relatively large, although negative, was 1971. It seemed plausible to assume that expectations of dollar depreciation plus certain capital export 
restraints had led to unrecorded capital outflows in that year. The revolution in Iran in 1978 and the second oil crisis, combined with rapid accumulation of wealth in OPEC hands and the U.S. freeze of Iranian assets, were all considered potential contributing factors to the unrecorded inflows in 1979 and 1980.

b. Evidence of unreported capital flows

In general, it is not possible to check the data on U.S. capital flows used in the international transactions accounts against data on the same transactions from other sources. Most countries do not collect detailed information on capital flows, by country. Moreover, even where they do, there is little basis for deciding which data are correct. In addition, analysis is complicated by the central role of financial centers like London, which do not collect data on transactions by foreigners in foreign securities. For example, in the U.S. data, new issues of Eurobonds by U.S. corporations show up as sales of securities to underwriters in the United Kingdom, but the U.K. data would not include these transactions.

Data comparisons are possible with the few countries that collect detailed data on capital flows broken down by country and for certain bank transactions. In both cases, these data comparisons suggest that there may be substantial errors and omissions in the data on U.S. international capital flows included in the U.S. international transactions accounts.

Much has been made in the press in recent years about apparent discrepancies between U.S. and Japanese data on Japanese purchases of U.S. Treasury securities. Unfortunately, precise comparisons are not possible on the basis of published data because it is aggregated in 
somewhat different ways. ${ }^{1}$ The U.S. data indicate that residents of Japan (both official and private) purchased net virtually no U.S. Treasury securities in 1986 or 1987 and that, with purchases of other bonds and stocks, Japanese investments in U.S. securities amounted to approximately $\$ 13$ billion in 1986 and $\$ 14$ billion in 1987 . Japanese data indicate private Japanese residents alone purchased net $\$ 49$ billion in U.S. securities in 1986 and $\$ 37$ billion in 1987. Anecdotal evidence would seem to support the Japanese data, but this impression is largely based upon the participation of the U.S. offices of Japanese-owned securities firms in the U.S. Treasury auctions. These offices did not report significant net sales of Treasury securities to Japan in these years.

It is likely that the discrepancy between U.S. and Japanese data on securities purchases reflects inadequacies in both reporting systems. Confusion about reporting responsibility is likely to occur in the U.S. system when the U.S. offices of Japanese firms place orders for securities for their head offices. The seller of the securities may not know that the purchaser is the foreign office, while the U.S. office of the Japanese firm may not report the sale because, technically, they never owned the securities. However, confusion is also possible in the Japanese reports of transactions by country. Transactions may be reported according to the nationality of the debtor, where the security is 1 isted, or according to the residence of the transactor. Only if the data is reported on the last basis would it be consistent with the U.S. data and, therefore, a check on U.S. data accuracy. In the U.S. data, Japanese purchases of Treasury securities in the London market or 
purchases of Eurobonds issued by U.S. corporations would not be recorded as sales to Japan.

In addition to comparisons of U.S. data with data collected by other countries for balance of payments purposes, it is also possible to compare U.S, data with data collected by bank regulatory authorities. The BIS receives reports from a large number of countries on banks' claims on and liabilities to bank and nonbank residents of many countries. (These data on cross-border bank transactions are also published in modified form by the International Monetary Fund.) In theory, the claims of banks in a foreign country on U.S. banks should match the liabilities of U.S. banks to banks in that country. In practice, precise comparisons are difficult because of differences in definitions. Many foreign countries include in their reports holdings by banks of securities issued by U.S. banks; U.S. banks exclude securities from their reported liabilities. (Changing the U.S. reports to include these would be difficult because the banks have little information on who holds their securities.) U.S. banks include in their reports custody holdings of negotiable instruments such as bankers acceptances and commercial paper, which need not be the liabilities of banks in the United states. In addition, they report as custody liabilities, loans to U.S. nonbanks that are booked at their offices outside the United States. In foreign reports, these would be included in claims on U.S. nonbanks. The BIS and the IMF are currently working on comparisons of countries' data and attempting to explain the reasons for discrepancies.

Finally, some comparisons are possible between the U.S. international transactions data and data collected by the Federal Reserve Board on U.S. nonbanks' borrowing from and deposits at banks outside the 
United States. A special survey covering the end of 1982 , done by the Federal Reserve with the cooperation of foreign governments, indicated that the U.S. International transactions data understated dollar deposits abroad of U.S. nonbank residents by about $\$ 75$ billion and claims of banks abroad on U.S. nonbanks by about $\$ 25$ billion. A clarification by the U.S. Treasury of reporting responsibility in mid-1986 led to a significant improvement in coverage of bank loans to U.S. nonbanks in the U.S. data, although the question of when these capital inflows occurred was left unanswered and some inflows still appear to be omitted.

However, the large omission of deposits outside the United States has not been dealt with. The Federal Reserve now regularly collects data on such deposits for inclusion in M3, but these data are not used in the U.S. international transactions accounts because of unresolved problems of double-counting and the lack of geographic information. Comparison of Federal Reserve data with the U.S. International transactions data indicates that substantial capital flows continue to be omitted. BIS data on banks' liabilities to U.S. nonbanks are roughly comparable to the Federal Reserve data.

There are substantial reasons to believe that inadequacies in the reporting of U.S. capital flows are likely to increase in coming years. Growing securitization of international capital flows has shifted transactions off the balance sheets of banks, who tend to be relatively accurate reporters. In addition, the growing sophistication of U.S. corporations and individuals has increased the volume of transactions directly with intermediaries located outside the United States (and beyond the reach of U.S. reporting requirements). In either case; it is much easier to monitor reporting by a few large banks then to gather 
accurate information from thousands of corporations and wealthy investors. Moreover, technological changes and innovations require constant monitoring and efforts to clear up questions of reporting responsibilities that were not foreseen when report forms were designed.

\section{b. Inadequacies of data on investment income}

If the data on U.S. capital flows are inadequate, then certain components of investment income will be inadequate as well. There are no direct reports of income on private portfolio claims and liabilities and only partial reports on U.S. government interest payments to foreigners. These income flows are estimated by the Department of Commerce from information on the level of assets and estimated rates of return. Estimates of the level of assets depend, in turn, on periodic benchmark surveys combined with subsequent recorded capital flows and rough valuation adjustments. Benchmark surveys of foreign portfolio investments in the United States are conducted regularly, but the last survey of U.S. portfolio assets abroad dates from World War II. Errors in valuation adjustments made since that date could potentially cumulate to a substantial sum. In addition, omission of capital flows from the reporting system, such as the increase in U.S. nonbanks' Eurodollar deposits discussed above, would lead to the understatement of portfolio investment income. Based on alternative (higher) estimates of U.S. nonbanks deposits at banks abroad and liabilities to banks abroad, the IMF working party estimated that U.S. net investment income was underestimated by about $\$ 4$ billion in 1983. Since 1983, TIC reporting of liabilities to banks abroad has been 1mproved, but reporting of claims has not, so current U.S. net investment income is probably underestimated by several billions more. 
Errors will also be introduced into the estimates of portfolio investment income if the Commerce Departments' estimates of rates of return are inaccurate. Commerce does periodically review the rates they use with major banks and other financial institutions, attempting to keep up with the evolution of financial markets. However, there are inevitable problems; to illustrate, the role of the prime rate in bank lending has diminished dramatically in recent years and the spread over Libor paid by particular countries may vary. In addition, the capital flows data frequently aggregate a mixture of instruments that pay differing rates of return; 1ittle information is available on how they should be weighted. For example, data on debt securities with maturities of more than one year are aggregated. However, the interest on 30 -year bonds can differ substantially from the rate on 2 -year notes that are due in 30 days. Moreover, fees on off-balance sheet transactions are becoming increasingly important to banks; efforts are currently underway to improve estimates of income associated with these transactions. In conclusion, despite the best efforts of the Department of Commerce, there are, undoubtedly, inaccuracies in the rates of return they use to estimate portfolio investment income. However, it is not clear that there would be any systematic bias in these errors, leading to a consistent over or underestimation of receipts or payments.

In contrast to private portfolio receipts and payments, direct investment receipts and payments are directly reported by businesses. The reporting system is extensive and missing reporters are likely to be small investors, not accounting for large amounts. However, the very low rate of return on assets reported by foreign direct investors in the United States does raise questions. Much foreign investment in the 
United States (as well as U.S. direct investment abroad) is in the form of wholly owned subsidiaries; companies try to minimize their tax burdens by using intercompany transactions to shift profits from high to low tax jurisdictions. The IRS recently reached an agreement to collect substantial back taxes from Toyota and Nissan on the grounds that they understated their U.S. profits by overcharging their affiliates for imported cars. If they had declared the same inflated value for the cars when they were imported, this would just shift payments from services to merchandise trade and not contribute to the statistical discrepancy. However, apparently it was common practice to declare a lower value for customs purposes than was used in calculating profits (contributing a negative value to the statistical discrepancy); the IRS has issued a rule in 1987 ending this practice by foreign investors in the United States. U.S. direct investors abroad have similar incentives to shift profits to lower tax jurisdictions, overstating direct investment receipts. However, this would have little impact on the statistical discrepancy unless they declared one price for exports to their affiliates in U.S. export documents and used another in calculating the profits of their affiliates. (The failure of multinational companies to adequately charge their foreign affiliates for $R \& D$ expenditures, central administration costs, etc., would just shift receipts from services to direct investment, and not affect the net current account.)

c. Inadequacy of data on other services and unilateral transfers The growing importance of services in the U.S. economy has led to efforts over the last decade to improve the coverage of services in the U.S. international transactions accounts. However many inadequacies remain. The Department of Commerce has just conducted a special survey 
of a wide variety of service transactions with foreigners that are currently not covered, including sales of information, computer and data processing services, legal and accounting services, etc. Depending on the results, regular surveys may be instituted to cover the most important types. In addition, the coverage of medical services provided to foreigners was added in 1987 and estimates are now included for fees earned by brokers and dealers on stock and bond transactions. Many gaps remain; the Commerce Department is currently working on ways to estimate education expenditures of foreign students in the United States and U.S. students abroad.

In addition to inadequacies in the coverage of many service transactions, the current estimates of immigrants transfers (which include only information on immigrants from Canada) undoubtedly underestimate the total. For a country like the United States, with a tradition of welcoming large numbers of immigrants, the omission of immigrants transfers from the international transactions accounts could contribute significantly to the positive statistical discrepancy (see Frankel and Long 1985).

\section{e. Inadequacy of data on trade}

It is generally assumed that the U.S. data on trade are reasonably accurate and that errors and omissions in these data could not explain wide swings in the statistical discrepancy from quarter to quarter. However, because imports are frequently subject to duties or quotas, they are likely to be more carefully tracked than exports. This point is illustrated by the results of the regular reconciliation meetings of U.S. and Canadian statisticians. Comparison of Canadian with U.S. customs data has led the Department of Commerce to increase U.S. 
exports in the published accounts by between $\$ 6$ and $\$ 10$ billion (or between 2.5 and 4.7 percent of the compiled total) in the years 1985 to 1987. However, the underreporting of exports to other countries is probably not as significant because, unlike the case with Canada, the compiled data does not depend on compliance with requirements that truckers place export documents in unmanned drop-boxes at large numbers of border crossings.

Another potential cause for concern is that fact that a significant part of U.S. trade is accounted for by transactions between multinational firms and their affiliates. Transactions between U.S. corporations and their majority-owned foreign affiliates accounted for approximately 25 percent of U.S. merchandise exports and 15 percent of U.S. merchandise imports in 1986. Transactions between foreign companies and their U.S. affiliates accounted approximately for an additional 10 percent of U.S. exports and 25 percent of U.S. imports in 1986. No information is available on what part of this trade is with wholely-owned affiliates, but in cases where transactions are between parts of the same firm, prices charged affiliates or declared for customs purposes may not accurately reflect market values. Presumably, the declared values of imports subject to customs duties are carefully monitored, but the values declared on other transactions are probably not scrutinized as carefully, and may deviate substantially from market value.

e. Conclusions on the adequacy of reporting systems

In conclusion, detailed examination of the U.S. international transactions accounts reveals many components that are inadequately covered or where the data appear to be inaccurate. Efforts are underway to improve the data, but results in many cases would require significant 
expenditures of money and increases in reporting burdens. Moreover, many improvements would not necessarily reduce the large positive statistical discrepancies observed in recent years.

\section{Statistical Analysis}

In addition to examining the adequacy of data on components of the U.S. international transactions accounts, it is possible to explore the sources of the statistical discrepancy in the accounts by examining correlations with other data.

In order to explore whether the statistical discrepancy behaves like unrecorded net capital inflows, I have looked at the correlation with recorded net capital inflows, components of recorded inflows, and variables that are conventionally used to explain capital flows such as interest rate differentials, expected exchange rate changes, and $L D C$ capital flight.

It should be recognized that the insights obtained from correlations between the statistical discrepancy and recorded net capital inflows or components of recorded inflows are limited. Lack of correlation between the statistical discrepancy and a particular component of the balance of payments accounts does not prove that there are not substantial errors and omissions in reporting of that component. The correlation would be high'only if a stable fraction of the balance of payments component were unreported. Moreover, since the balance of payments accounts are a double entry system, any correlation between the statistical discrepancy and a particular component of the accounts could be interpreted in two ways: either reporting of that component is inadequate or reporting of the other side of the transaction is inadequate. Sign does not necessarily indicate which interpretation is 
correct; for example, a negative correlation of the statistical discrepancy with foreign purchases of corporate securities could indicate either that sales of securities were being missed or that the reporting of the assets that investors were switching out of in order to pay for the securities was inadequate. In addition, the correlation results must be treated with caution because the estimates have been unstable; the addition or elimination of a few observations can change the results. With these caveats in mind, table 3 shows the results of regression with various components of the international transactions accounts. All components were net to avoid spurious correlation because both the statistical discrepancy and almost everything else has gotten larger since 1970. Multiple regressions were not tried because the statistical discrepancy is, by definition, equal to the sum of the other components in the U.S. international transactions accounts with the reverse sign. The statistical discrepancy appears to be positively correlated with net direct investment inflows (equation 6), but negatively related to other capital inflows (equation 7), particularly bank reported inflows (equation 8). One hypothesis that would be consistent with these results is that capital flows involving banks are more accurately reported than other flows, and when flows shift to other channe1s, errors and omissions rise.

Table 3 also shows the results of a regression relating the statistical discrepancy to variables that might be used to explain net capital flows (equation 12): the differential between U.S. and weighted average foreign long term interest rates and expected exchange rate changes (where it is assumed that actual exchange rate changes were correctly expected). These variables do not explain much of the 
variation in the statistical discrepancy, but it does appear that the statistical discrepancy rises when U.S. interest rates rise relative to foreign.

The next regression (equation 13 ) on table 3 relates the statistical discrepancy to one measure of capital flight from Latin America and the Philippines. Capital flight is crudely measured as equal to the gross external debt of these countries plus the inflow of net foreign direct investment minus the current account deficit minus the change in external assets of the central bank and the commercial banks. The $\mathrm{R}^{2}$ in this equation is not comparable to those in the other regressions because the data are annual rather than quarterly. However, the correlation appears strong and the coefficient appears high, implying that about half of every dollar of capital flight from these countries ended up in unrecorded U.S. capital inflows.

In conclusion, although these regression results must be viewed only as suggestive because of the dangers of spurious correlations, they do seem to support the view that at least part of the statistical discrepancy in the U.S. international transactions accounts is the result of errors and omissions in the reporting of capital flows.

Table 3 also reports the results of regressions relating the statistical discrepancy to components of the current account. There appears to be a negative relationship between the trade balance and the discrepancy (equation 1). One possible explanation is that a fraction of the capital inflow necessary to finance the trade deficit is unreported. There is a positive, but not statistically significant relationship with the services balances (equation 2). This positive relationship is supported by a regression relating the statistical discrepancy to the 
level of U.S. interest rates (equation 14); if interest income were being underreported, the amounts involved would tend to increase as interest rates rose.

\section{Conclusions on the U.S. Statistical Discrepancy}

There are strong reasons to suspect errors and omissions in the reporting of both current and capital account transactions in the U.S. data. Inspection of the reporting systems and correlations between the statistical discrepancy and various variables confirm these suspicions. However, it is very difficult to quantify the contribution of current account vs. capital account transactions to the statistical discrepancy. It would seem safe to assume, however, that the shift of the U.S. current account from near balance in the first 3 years of the 1980 s to deficits of around $\$ 150$ billion in recent years cannot be accounted for by errors and omissions; the direction of change is clear, although the exact magnitude of the deficit could be significantly below $\$ 150$ billion.

\section{INTERNATIONAL INVESTMENT POSITION DATA: GLOBAL}

Net debtor positions as well as current accounts are frequently mentioned as indicators of sustainability and the need for policy adjustments. Unlike the current account data, which are readily available for a large number of countries on a consistent basis from IMF sources, data on international investment positions must be collected from national sources. The difficulties of measuring a country' net investment position will become apparent in the next section of the paper, where the U.S. net investment position is examined in detail. Moreover, since there are no commonly agreed guidelines on how assets and liabilities should be valued, it is unlikely, even if data were available 
from all countries, that the sum of all countries' positions would equal zero.

With this caveat in mind, table 4 shows net external assets (excluding gold) for the 7 major industrial countries and IMF projections for 1987 through 1989 (IMF 1988, 89). Over the next few years, these countries as a group are expected to move into a large negative position. According to the IMF, "Given that the recorded debt stock of the capital importing countries, which amounted to $\$ 1200$ billion at the end of 1987 , is unlikely to be fully matched by the assets of the smaller industrial countries and the capital exporting countries in the Middle East, the data presented here would seem to confirm the existence of a very large amount of cross-border assets recognized by debtor countries but which do not seen to be reflected in the statistics of creditor countries" (IMF $1988,90)$.

This theme is examined in more detail in the Report on the World Current Account Discrepancy (IMF 1987). The IMF working party concluded that the underreporting of assets was widespread across countries; in particular, estimates of the international claims and liabilities of nonbanks appear to be deficient. Some idea of magnitudes can be inferred from the other side of transactions: bank records of claims on and liabilities to nonbank foreigners. The reasons for the inadequacy of data on nonbanks assets and liabilities vary but include evasion of taxes and exchange controls and ignorance of reporting requirements. This problem has been exacerbated in recent years by the securitization of International lending; information on issuers of securities in international bond markets is readily available, but little information is available on the purchasers of these securities. 
In conclusion, it appears that there is significant underreporting of claims in many countries' net investment position data. However, forecasts of current accounts are likely to provide a reasonable indication of directions of change and, in many cases, of future trends in investment income payments. Moreover, in the case of highly indebted countries that have experienced significant capital flight, the fact that some residents of the country have assets hidden abroad and are earning income on these assets may be of little use if these assets are beyond government control.

\section{E. U.S. NET INTERNATIONAL INVESTMENT POSITION}

According to the Department of Commerce, foreign assets in the United States exceeded U.S. assets abroad by approximately $\$ 368$ billion at the end of 1987 (see table 5). This net debtor position is a recent development; from World War I through 1984, the United States was a net creditor to the rest of the world, with the net asset position reaching a peak of $\$ 141$ billion in 1981 . The sharp reversal in recent years is a result of the large net capital inflows associated with growing U.S. current account deficits. Valuation changes estimated by the Department of Commerce play some role in explaining changes in position from year to year, but, in recent years, these valuation changes have been small relative to recorded capital flows.

As acknowledged by the Department of Commerce, these data are a rough indicator and not a precise statistical measure of U.S. net indebtedness to foreigners because of errors and omissions in the U.S. international transactions data and because of valuation problems. Errors and Omissions 
As discussed earlier, the statistical discrepancy in the U.S. international transactions accounts has been large and positive for the past decade, indicating some combination of omitted net exports of goods and services and omitted net capital inflows. In fact, cumulative net unrecorded transactions between 1959 and 1987 amounted to over $\$ 190$ billion. Since the published net investment data rely only on recorded capital flows, the real net investment position could be more negative. On the other hand, alternative sources of data indicate that U.S. nonbanks' deposits at banks outside the United States are seriously underestimated in the position data. As of the end of 1987, Federal Reserve data indicate that these deposits are at least $\$ 70$ billion larger than the amount included in the position data.

\section{Valuation Problems}

Apart from stocks and bonds, the Department of Commerce does not attempt to revalue assets according to market prices. And even in the case of stocks and bonds, the valuation methods may be subject to substantial errors.

\section{a. Securities}

The Treasury Department conducts periodic benchmark surveys of the value of foreign holdings of U.S. stocks and bonds (1ines 16 through 19). In between these surveys, reliance must be placed on data collected on new transactions and estimates of the change in value of previous holdings (based on movements in stock market price indices and interest rate movements). In estimating the investment position, $B E A$ is currently using data from the 1978 benchmark survey; however 1984 data will be available soon. Estimates of changes in value are necessarily crude since foreigners' holdings of stocks may differ in composition from the 
stocks included in various market averages and since little information is available on the term structure of foreigners' holdings of bonds.

For U.S. holdings of foreign stocks and bonds (1ines 8 and 9), the latest benchmark survey was conducted during World War II; no survey has been conducted since then because of the tremendous difficulty and expense of obtaining accurate data. As a result, the current estimate of holdings is based upon data on transactions since World War II and valuation adjustments based on foreign stock market indices, interest rate and exchange rate movements. The task of valuing U,S. holdings of foreign securities is made even more difficult by the fact that purchases and sales data are collected on the basis of the nationality of the transactor, and not the issuer; transactions through financial centers like London need not reflect purchases or sales of U.K. securities. As a result, it certainly is possible that the errors in the estimated valuation adjustments to U.S. holdings of foreign securities could have cumulated to a substantial sum since World War II.

b. Gold

U.S. official reserve holdings of gold (included in line 3) are valued at the official price ( $\$ 42.22$ per ounce), while the market price is about 10 times higher. U.S. assets would be about $\$ 100$ billion larger if gold were valued at current market prices.

\section{c. Direct investment}

In addition, direct investment claims (line 6) and liabilities (1ine 15) are at book value. It seems likely that this valuation understates the market value of U.S. direct investment abroad by more than it understates the value of foreign direct investment in the United States because foreign direct investment in the United States is, on 
average, more recent than U.S. direct investment abroad. One way of crudely estimating market value would be to assume that the market value of investments (measured in dollars) increases proportionately with inflation and exchange rate changes. Starting with the book value of direct investment assets in 1964, inflating each year by a weighted average foreign price index adjusted for exchange rate changes, and adding the new capital outflow yields an estimate of the value of U.S. direct investment assets of about $\$ 700$ billion at the end of 1987 . Using the same methodology, estimated foreign direct investment in the United States would be $\$ 350$ billion, and the net position would be $\$ 350$ billion, $\$ 300$ billion larger than the net included by the Department of Commerce.

Comparison of the size of direct investment receipts and payments suggests that the market value of U.S. assets abroad may exceed the market value of foreign assets here by even more. The ratio of reported receipts to payments in recent years has been about 3 to 1 , in contrast to the 2 to 1 ratio estimated above. However, this ratio calculated using receipts and payments may be distorted by temporary factors which inflate or depress earnings; if generally perceived as temporary, they would have a limited effect on the market value of assets. In addition, many affiliates of foreign companies in the United States and foreign affiliates of U.S. companies are wholly-owned subsidiaries; the parent companies enjoy considerable latitude in determining charges for transactions with their subsidiaries, and tax considerations may play a significant role in determining where profits are reported.

\section{d. Bank claims and 1iabilities}


Bank reported claims on and liabilities to foreigners (lines 11 and 21 ) are also at book value. No adjustment is made, for example, for the market value of loans to countries experiencing debt servicing problems (as long as the banks continue to carry the loans on their books at full value).

\section{Conclusions}

The net international investment position of the United States, as published by the Department of Commerce, is subject to a substantial margin of error because of the errors and omissions in the U.S. international transactions accounts and because of valuation problems. However, given the magnitude of recent U.S. current account deficits, there is little doubt that the published data correctly indicate the direction and rough magnitude of change.

\section{F. USEFULNESS OF CURRENT ACCOUNT AND POSITION DATA AS INDICATORS OF}

\section{DISEQUILIBRIUM}

Even if data were completely accurate, a given current account and investment position may not clearly indicate the need for policy changes because of lags in the adjustment process or underlying long run trends.

\section{Lags}

The problem with using observed current account positions as an indicator of disequilibrium requiring policy adjustments can be illustrated by considering the current U.S. situation. Estimates of whether substantial further depreciation of the dollar is necessary to correct the U.S. current account deficit depend crucially on whether all or only part of the impact of the depreciation of the dollar from its 
high of February 1985 has been realized. Given current techniques for estimating the length and shape of lagged adjustments, it is possible for different econometricians to arrive at very different conclusions using the same data. This problem has been discussed extensively elsewhere, for example at the January 1987 Brookings workshop on the U.S. external deficit, and I do not intend to repeat it. (See Bryant, Holtham, and Hooper, eds. 1988, 101-139.)

Underlying Long Run Trends

Another problem with using current account or investment position data as an indicator of required policy adjustments is the need to take into account underlying trends. For example, it may be appropriate for a country with a rapidly aging population to run current account surpluses and accumulate assets in preparation for future years when a large retired population must be supported. There are many additional factors which might mean that it would be unwise to identify current account balance with equilibrium and current account surpluses or deficits with disequilibrium. I plan to focus on only one of these: the implications for future U.S. net investment income of the growing U.S. net international indebtedness.

Many observers have concluded that the United States will have to run substantial trade surpluses in the future to cover large net payments of investment income on the U.S. net debtor position. Crude estimates are arrived at by assuming that the U.S. net debt will accumulate to $\$ 1$ trillion and by assuming an interest rate, for example 7 percent, producing an estimate of around $\$ 70$ billion per year in net interest payments. These back-of-the-envelop calculations probably 
substantially overstate the net interest payments that are likely to be associated with a recorded U.S. net investment position of that size.

The reasons for this are twofold: first, the rate of return on U.S. assets abroad tends to be higher than the rate of return on foreign assets in the United States, and, second, while U.S. 1iabilities are growing more rapidly than U.S. assets, both are likely to continue to trend upwards. The combined effect of these factors is illustrated by the fact that net investment income was positive in 1987 despite a sizable net debtor position. U.S. net investment income would tend to increase if our net debtor position were not growing.

\section{a. Relative rates of return}

Two questions are apparent: is this differential in rates of return likely to persist in the future and does it represent a real difference or just a recorded difference in rates of return? Turning first to direct investment, table 6 shows the rate of return on direct investment as published by the Department of Commerce. Because the direct investment position used in these calculations is measured at book value, and since direct investment in the United States is, on average, more recent than U.S. direct investment abroad, the value of U.S. direct investment abroad is more seriously understated because of inflation than the value of foreign direct investment in the United States. If the rates of return are recalculated using Department of Commerce capital flows data, adjusted for inflation and exchange rate changes (also shown on the table), the differences are reduced substantially, but some margin remains.

Some differential might be expected on the grounds that some U.S. direct investment abroad is located in countries where political and 
economic risks are significant. However, a major part of the differential is probably the result of tax incentives which lead multinational firms to use transfer prices to shift reported profits to lower tax jurisdictions abroad. Although U.S. corporate tax rates were lowered recently relative to other industrial countries, they still remain above rates in various tax havens. The incentive to report profits abroad will probably persist, inflating reported receipts on U.S. direct investment abroad and depressing payments on foreign direct investment in the United States. Balancing this distortion of the direct investment accounts is the underreporting of exports of goods and services by U.S. corporations to their affiliates abroad and the overstatement of the imports of goods and services by the U.S. affiliates of foreign companies. These understatements of net credits on other current account items are likely to grow as direct investment in and out of the United States continues to expand, so errors in the returns on direct investment are likely to be matched by equal and opposite errors in other current account items.

Turning now to portfolio investment income, table 7 shows the average rates of return implicit in the data published by the Department of Commerce on income and position. The implicit rate for private payments has been consistently below the rate for government payments and private receipts. There are several explanations for this. First, at the end of 1987, foreign holdings of U.S. equities amounted to $\$ 173$ billion, somewhat less than 20 percent of the U.S. private sector's portfolio liabilities to foreigners while U.S. holdings of foreign equities amounted to only $\$ 56$ billion, less than 10 percent of U.S. private portfolio claims on foreigners. Since dividends generally 
provide only a part of the expected return on equities, and since capital gains on stocks are excluded from the balance of payments accounts, the average rate of return on both portfolio claims and liabilities is brought down, but the impact is larger on the payments side.

Second, the bulk of U.S. portfolio claims and liabilities are reported by banks: about three-quarters of private claims and threefifths of private liabilities. As intermediaries, banks make profits by earning more on their assets than they pay on their liabilities. ${ }^{2}$ In addition, the Department of Commerce includes in receipts of income on U.S. assets abroad estimates of fees earned by banks in the United States for various services provided to foreigners. In response to pressures to improve capital adequacy, major U.S. banks have slowed the growth of their balance sheets and have focused increased attention on profitable off-balance sheet transactions. Fees from these off-balance sheet services to foreigners are likely to continue to grow in the future. Finally, U.S. nonbanks are likely to be paid a higher rate of return on their dollar deposits abroad than foreigners are paid on their bank deposits in the United States because of the absence of reserve requirements and deposit insurance charges in the Eurodollar market.

\section{b. Growth of gross claims and liabilities}

Despite the shift to a net debtor position, U.S. assets abroad have continued to grow, illustrating the continuing internationalization of financial markets and the use of U.S. financial institutions as intermediaries by foreigners. As can be seen on chart 2, the rate of growth of U.S. portfolio claims on foreigners has slowed in recent years, as the U.S. current account deficit has grown. However the deceleration is exaggerated by the rapid growth of bank claims in 1981 and 1982 ; in 
these years banks shifted business from the books of their affiliates outside the United States to their newly established International Banking Facilities (IBFs). The slower growth of bank claims in recent years also has been associated with the debt crisis and efforts to Improve capital adequacy as well as a slowdown in inflation. As a result, one might expect the rate of growth of U.S. private portfolio claims on foreigners to remain somewhat below the average for the 1970 s and early 1980s, but to remain significant.

U.S. direct investment assets abroad have also continued to grow in recent years, although the year to year changes are sensitive to fluctuations in economic activity (and currency translation effects). U.S. based firms are likely to continue to invest in growing economies abroad and the pressures of international competition are likely to continue the trend toward global sourcing and expansion of production facilities in countries with lower costs.

\section{c. Implications for U.S. net investment income}

The simulations done with the Multicountry Model of the Federal Reserve Board for the Brookings Conference on the U.S. Current Account (January 1987) illustrate the implications of continuing growth of U.S. gross claims on foreigners for future net investment income. Between 1986 and 1991 the U.S. net investment position declines by $\$ 746$ billion, from $-\$ 280$ billion to $-\$ 1026$ billion. However, U.S. net investment income declines only by $\$ 23$ billion, from $\$ 22$ billion to $-\$ 1$ billion. These numbers are just illustrative; they should not be interpreted as a forecast because the underlying assumptions are somewhat arbitrary and have, in many cases, been overtaken by more recent developments. But they do illustrate the point that underlying trends must be taken into 
account, along with current account positions, in analyzing necessary policy adjustments.

\section{E. CONCLUSIONS}

The data on U.S. and other countries' current accounts and international investment positions appear to be subject to a considerable margin of error. However, large shifts in recorded data are unlikely to be illusory. There is little doubt that the United States has been running massive current account deficits in recent years and that the rest of the world has accumulated large claims on the United States as a result. While the data may be accurate enought to discern broad trends, current account and net investment positions do not always yield unambiguous signals of the need for policy adjustments. This is illustrated by the current debate over the appropriate exchange rates for the U.S. dollar. 


\section{Lois Stekler}

\section{BIBLIOGRAPHY}

Bryant, Ralph, Holtham, Gerald, and Hooper, Peter, editors, External Deficits and the Dollar, Brookings Institution, Washington, D.C., 1988 .

Franke1, Allen and Long, Alice, The Treatment of Immigrants' Transfers in U.S. International Transactions Data, Unpublished memo, Federal Reserve Board, Washington D.C., January 3, 1985.

Helkie, William and Stekler, Lois, Modeling Investment Income and Other Services in the U,S. International Transactions Accounts, International Finance Discussion Paper Number 319, Washington, D.C., December 1987.

IMF, Report on the World Current Account Discrepancy, IMF, Washington D.C. September 1987 .

IMF, World Economic Outlook, April 1988, IMF, Washington D.C., 1988.

Krueger, Russell C., "U.S. International Transactions, First Quarter 1988 , in U.S. Department of Commerce, Survey of Current Business, June 1988 .

Scholl, Russe11, "The International Investment Position of the United States in 1987", in U.S. Department of Commerce, Survey of Current Business, June 1988 . 


$$
\text { Lois Stekler }
$$

\section{END NOTES}

1. The published U.S. data aggregate official and private purchases of U.S. Treasury or other securities by Japan, while the Japanese data exclude central bank purchases of securities and do not distinguish between U.S. Treasuries and other long term bonds.

2. The IMF Working Party on the statistical discrepancy in world current account balances used a spread of 250 basis points between the rate earned on bank claims on nonbanks and the rate paid on liabilities to nonbanks; the spread on interbank transactions is much smaller. 


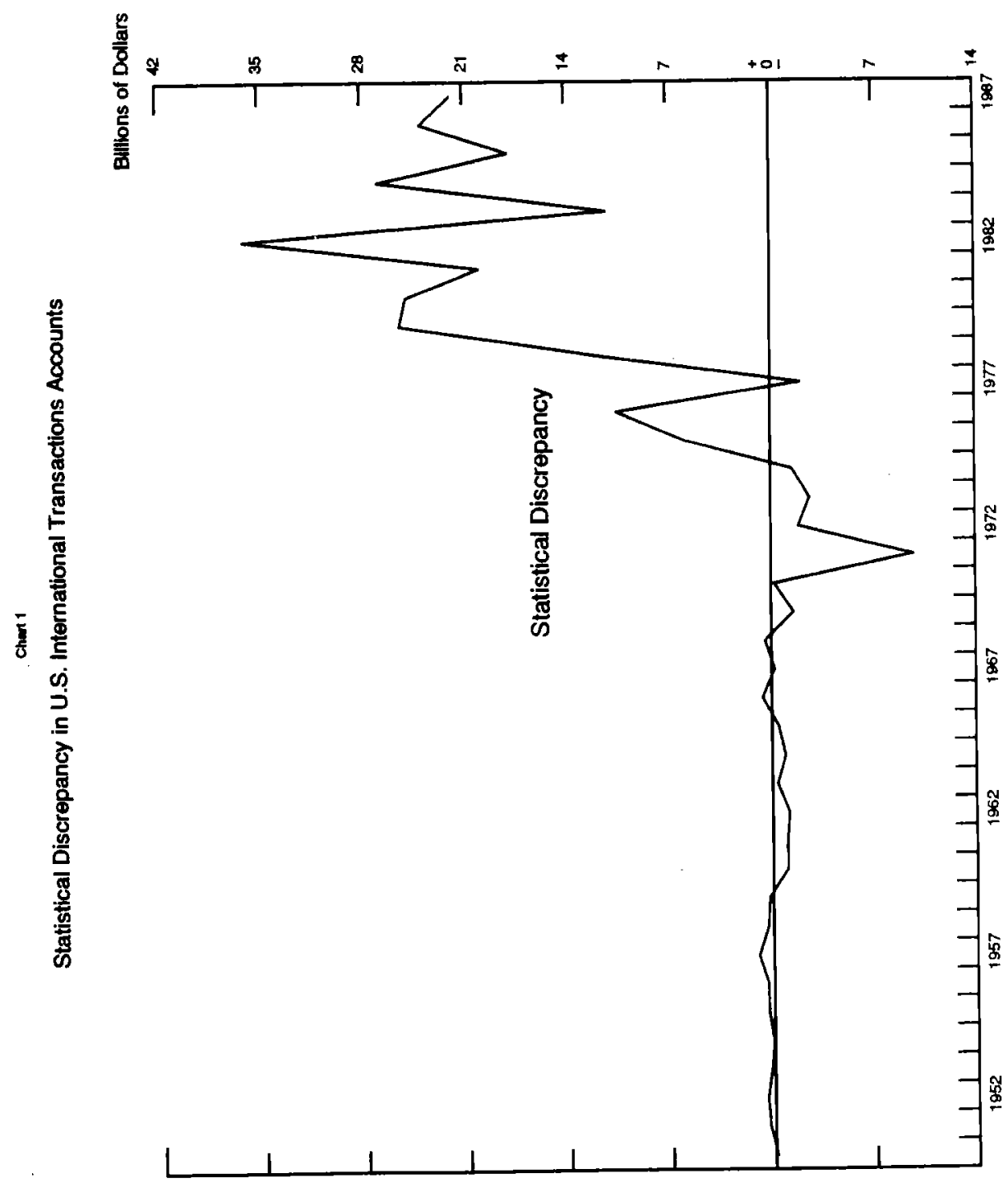




\section{U.S. International Investment Position}

Portfollo Claims and Liabilities

Billions of doliars

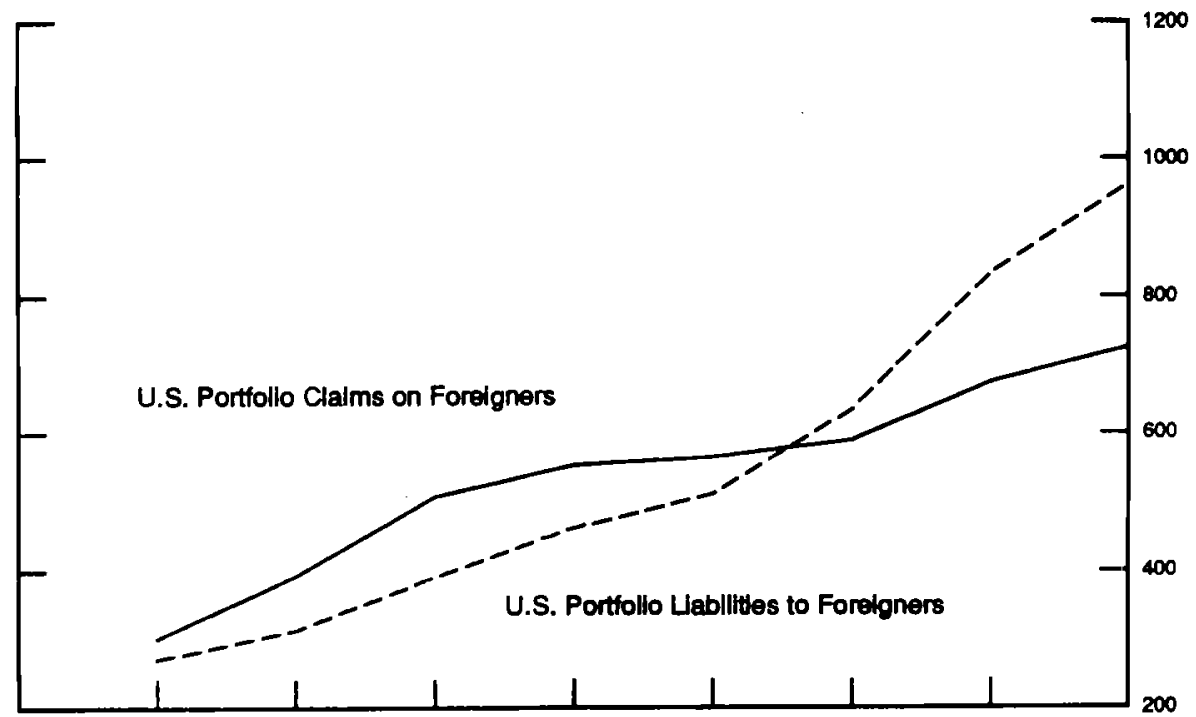

Direct Investment Claims and Liabilftes

Billions of Dollars

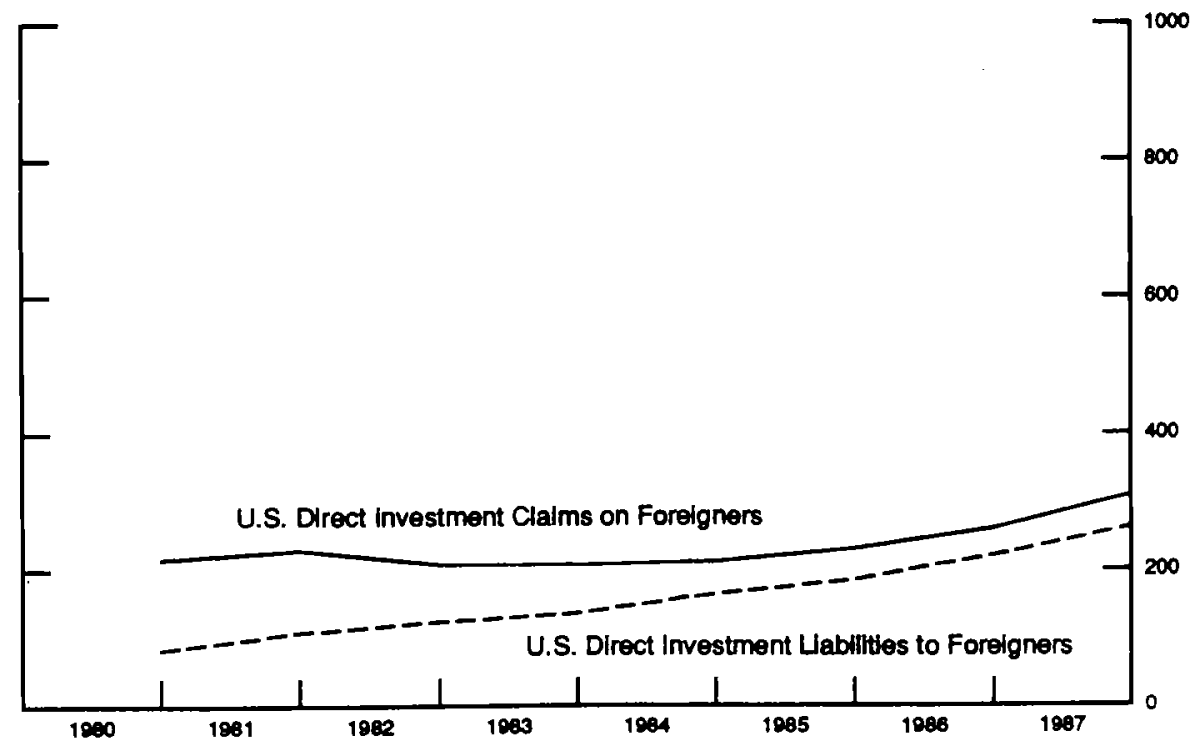




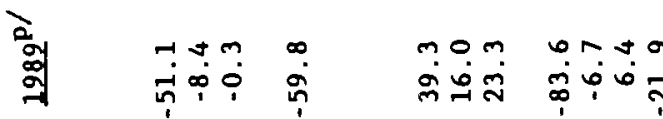

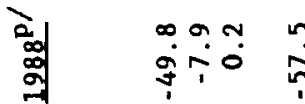

$\infty 0 \infty \quad+\infty N$

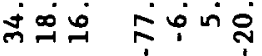

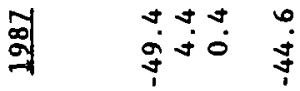

nิำ

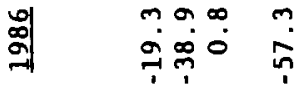

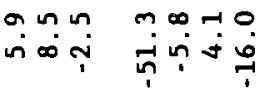

年

man 0 a

बं

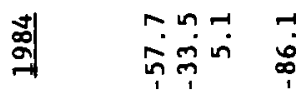

0.0. N n

बं

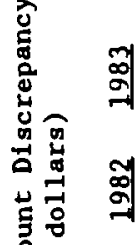

no

mon

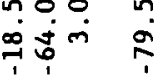

กิ

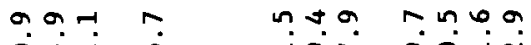

ๆึั

00

क्षै|

$000 \quad 0$

-în

- in $\infty$ nn $N$

正

空

구

舟宁

$\infty$ i $\infty$

o요

志

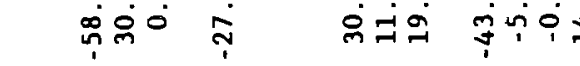

家

온

点 常

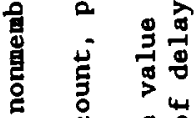

¿

× ¿

i

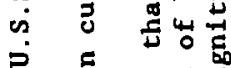

ป

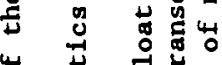

㟧出出

号 㟧

可

总 号 站

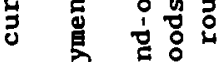

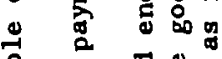

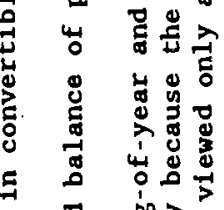

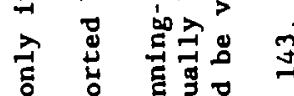

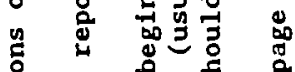




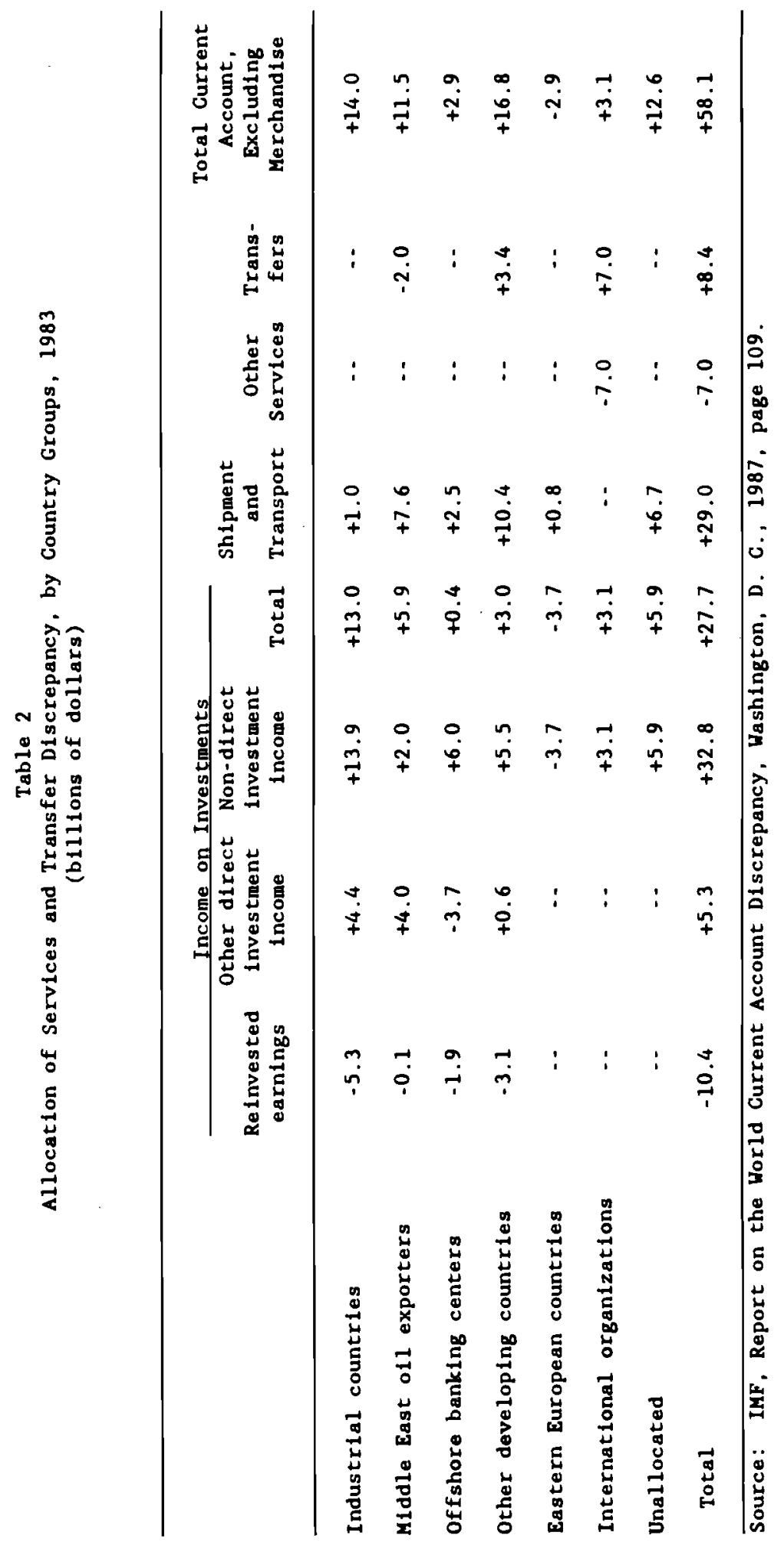


Table 3

Statistical Discrepancy Regressions 1

A. Components of U.S. Intermational Transactions (1970Q-1987Q4)

Explanatory Variable

1. Trade balance

2. Services balance

3. net investment income

4. other service income

5. Current account balance

6. Net direct investment capital inflow

7. Net other private capital inflows

8 . bank reported

9. nonbank reported

10. Net official capital inflow

11. foreign official inflow

B. Variables Used to Explain Capital Flows (1974Q1-1987Q4)

\section{Explanatory Variable}

12. Constant

U.S.-foreign interest differential $2 /$

Exchange rate change $3 /$

C. Capital Flight (1978-1987)

Explanatory Variable

13. Constant

Capital flight 4

D. U.S. Interest Rate Level (1970Q1-1987Q4)

Explanatory Variable

14. Constant

U.S. treasury bill rate 5/
Coefficlent

$-0.13$

0.32

0.43

0.53

$-0.10$

0.37

$-0.16$

$-0.18$

$-0.04$

$-0.09$

$-0.12$
Istat. $\mathrm{B}^{2}$

$-2.51 \quad .11$

$1.54 \quad .06$

$1.60 \quad .06$

$0.90 \quad .05$

$-2.02 \quad .09$
-02.23

$2.23 \quad .10$

$-2.94 \quad .12$

$-2.66 \quad .12$

$-0.36 \quad .04$

$-1.13 \quad .05$

$-1.28 \quad .06$

Soefficient I stat. $R^{2}$

$\left.\begin{array}{rr}3.9 & 6.01 \\ 1.1 & 2.66 \\ 16.7 & 1.03\end{array}\right\} .10$

Coefficient Istat. $\mathrm{B}^{2}$

$\begin{array}{rr}15.0 & 6.27 \\ .57 & 3.30\end{array}$

Coefficient $\mathrm{T}$ stat. $\mathrm{R}^{2}$

$$
\left.\begin{array}{rr}
-1.4 & -.78 \\
.6 & 2.63
\end{array}\right\}
$$

I All regressions were OLS with Cochrane-Orcutt correction. Data were

in billions of dollars. Annual data was used in the capital flight

regressions, quarterly data in all others (not including the seasonal discrepancy adjustment).

2 Interest rate on 10 year U.S. Treasury bonds minus the trade weighted average of rates on 10 year govermment bonds for the G-10 countries.

3 Change in the Federal Reserve trade weighted index of the value of the dollar against $G-10$ currencies ( $I_{t}-I_{--1}$ )/ $I_{t-I}$

4) Capital flight from 10 Latin fmerican countries and the Philippines.

Equal to the gross external debt plus the inflow of net foreign direct investment minus the current account deficit, minus the change in external assets of the central banks and the commercial banks.

5/ U.S. Treasury bill rate - 3 month, secondary market. 


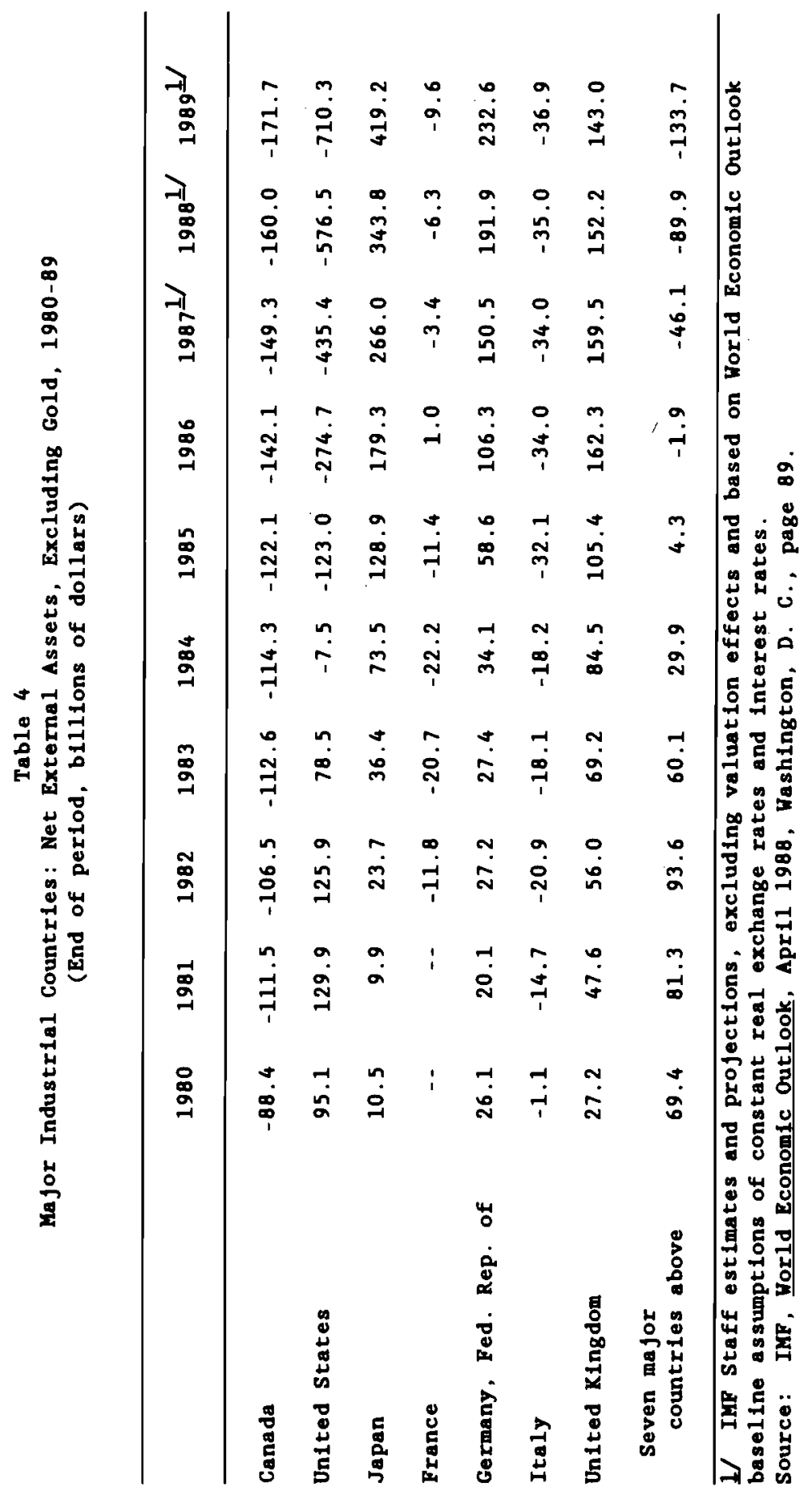




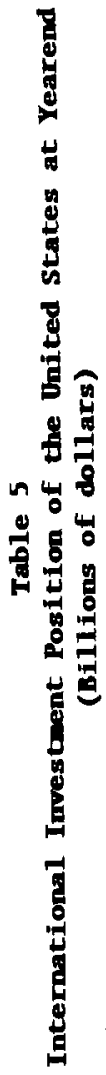

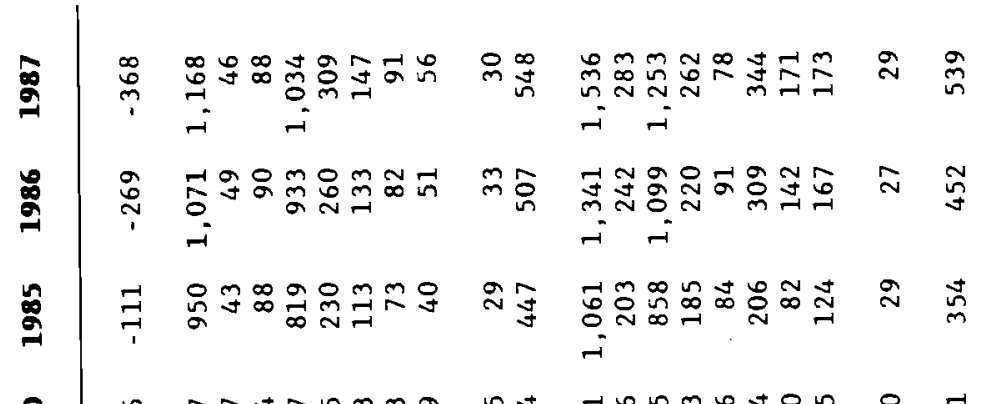

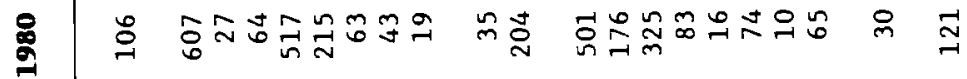

a

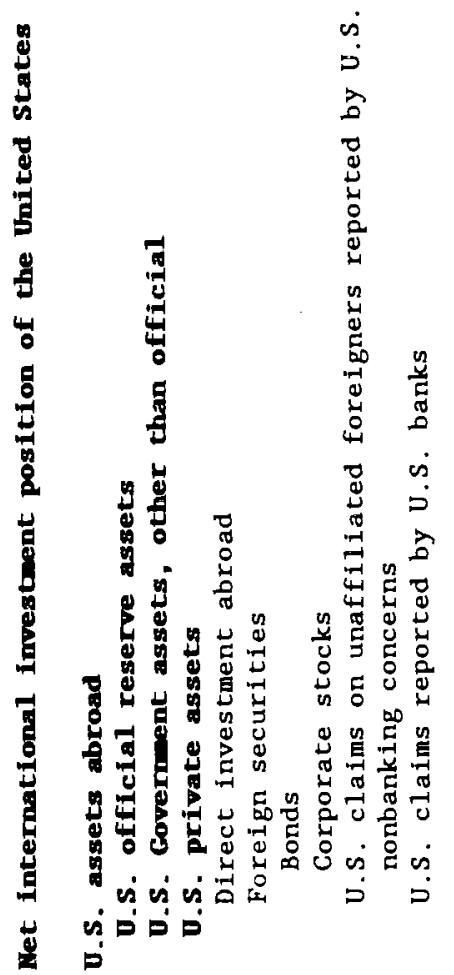

誌

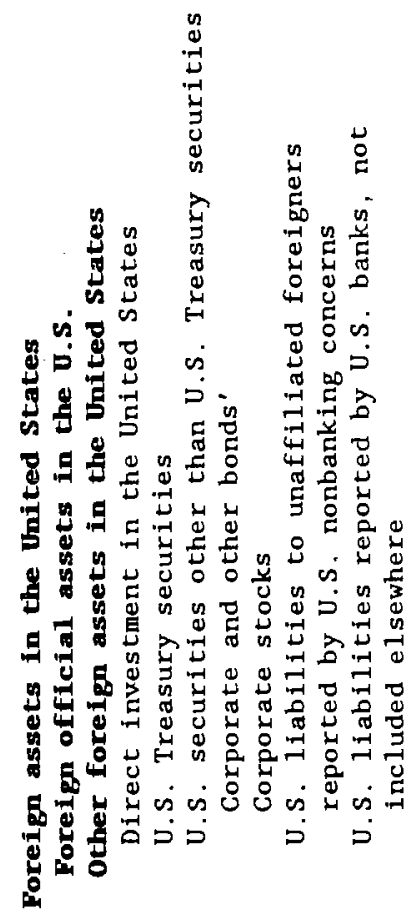


Table 6

Implicit Rates of Return on U.S. Direct Investments

U.S. Direct Investment Claims Dept. of Commerce Adjusted Basis

1980

1981

1982

1983

1984

1985

1986

1987
18.4

14.4

9.9

9.5

10.2

14.8

15.7

18.4
9.06

6.92

5. 24

5.87

6.65

6.28

5.46

5.95
U.S. Direct Investment Liabilities Dept of Commerce Adjusted Basis

15.4

9.8

2.6

4.3

6.1

3.5

2.7

4.4
7.11

5.13

1.88

2.66

4. 32

2.99

2.66

3. 24 
Table 7

Implicit Rates of Return on U.S. Portfolio Investments

\section{U.S. Portfolio Claims

Private Govt.

1980

1981

1982

1983

1984

1985

1986

1987
12.20

15.00

12.79

9.71

10.63

8.76

7.30

6.74
3.55

4.31

4.48

4.84

4.96

4.87

5.20

4.24
U.S. Portfolio Liabilities Private

$\begin{array}{rr}8.49 & 9.18 \\ 10.20 & 10.99 \\ 9.30 & 11.33 \\ 6.89 & 9.95 \\ 7.82 & 10.11 \\ & \\ 6.41 & 9.40 \\ 5.40 & 8.40 \\ 5.43 & 8.11\end{array}$

